\title{
Sympoetics of Place and the Red Dust of India
}

\begin{abstract}
Alex Berry
Alex Berry is a PhD student at Western University, located on the lands of the Anishinaabe, Haudenosaunee, and Lenape peoples. Situated at the intersection of childhood studies, the feminist environmental humanities, and the arts, Alex's research focuses on the liveliness of waste materials in early childhood spaces. Centering the studio (or atelier) as a site for research and curricula making, Alex is interested in how collaborative artistic processes may propose new ways of relating with waste materials in times of advanced capitalism. Email: aberry28@uwo.ca
\end{abstract}

Experimenting with forms that lie outside the boundaries of traditional ethnographic research, in this paper I think with Haraway's (2016) notion of sympoiesis as a platform to reimagine my engagements with place after recently returning home from my pedagogical work as visiting artist-researcher-teacher at a school in Goa, India. I imagine sympoetics as methodological engagement that conceives poetry, not as a purely individual, reflective practice, but rather a co-compositional performance that attends to the polymorphic, often contradictory relations of humans and materials as they are entwined with place. Following the ephemeral movements of India's red dust, I attend to the intersections of seemingly disparate materials, specifically a child's pencil and waste materials, and the ways in which they gather meaning together/apart among local/global red dust assemblages. By highlighting and decentering colonial undertones in ethnographic methodology with children and attending closely to anticolonial stories told through my relations with the red dust of India, this paper works to both sit with-and stir updiscomfort, toward more complex, contentious, and responsive accountabilities with place. Using sympoetics to trace the movements and impermanence of red dust, this performance is intentionally partial and aims to situate research in the midst of "not yet" and unknowability.

Key words: childhood; sympoetics; materiality; place; methodology
Red dust is always in motion and thus is never wholly known. Its form is eternally moving, momentarily composing shape and shifting to another. Red dust reconfigures the linguistic properties of its collective signifier, "form," to inventively perform as both noun and verb. Disrupting colonial notions of traditional ethnographic form, this paper uses sympoetics to center the form(-ations) of India's red dust in childhood studies. Borrowing from Haraway (2016), sympoiesis means "making-with," where making is a fundamentally co-compositional act within "collectively-producing systems that do not have self-defined spatial or temporal boundaries" (p. 61). Thinking beyond poetic writing as a purely reflective, individual pursuit, sympoetics offers an orientation to writing that notices, suspends, and holds together relations with materials and place in the midst of ambiguity that exists beyond the self. Using sympoetics to attend to anticolonial stories told through my relations with the red dust of India, this performance aims to stir up and settle into discomfort toward more affectual, contradictory, and contingent understandings of place relations in childhood studies research. 
I empty out a bejewelled bag of Goan trinkets and handmade giftsscarves, journals, bookmarks, earrings and small fabric packages of Indian spices.

Items made by hands much smaller than mine -carried a long way to be shared with others, to places I used to know. Laid over my bed, a mix-matched quilt of two worlds. The pieces of who I used to be. The new, the parts of me that have changed-hovering over the scene like oil and water. After taking out the last spice capsule of chana masala, I shake the bag upside down over my bed. Red dust particles fly over my sheets, sprinkling the crevices of my pillows with tiny footprints. The familiar smell of Goa dances around the room. A polymorphic composition of freshly baked breads, jasmine trees, cinnamon and cumin spice, of pigs and cows, vanilla incense, burning petrol, the delicacy of gulab jamun and the unparalleled artistry of fine Indian sweets. Its fragrance is a sensational choreography that can only be understood from the experience it offers, a vibrant sort of ordinary whose aroma is so multitudinous it can never be truly identified. Like the pungent memory of my great-grandmother's perfume, it overwhelms my senses. Genuine, warm-it feels like coming home.

My stomach reaches her hands and traces her fingers over the bottom of my heart. As blood pools to my core, it becomes heavy - full with memories of another life. Adjusting to its weight, I sit on my bed. Laying back into speckled sheets, I close my eyes and swallow hardpushing down on dry beads that tickle my throat. The ephemeral red dust of India. Back on the unceded soil of the Musqueam, Squamish, and Tsleil-Waututh First Nations, in what is also known now as Vancouver, Canada, I revisit my seemingly never-ending web of data, a desk overflowing with sticky notes, photos, art clippings, video files, penciled quotes and anecdotes-fleeting memories and endless curiosities-the colliding traces of my existence as a visiting artist-researcher-teacher at a school in Goa, India. ${ }^{1}$ The data ripples with lively stories of place that spill off its edges-the vibrant art pieces that unfolded with the children at the school where I worked, the people and materials I encountered, and the tensioned moments I provoked as a whitebodied visiting artist-researcher-teacher. Entering this desk of data is affectively overwhelming. I roll the wheels of my chair closer as I lean over its surface, my eyes scanning through its intricate pieces. But when I reach my fingers out to touch them, I sense a growing intensity in my body-beginning with a heavy pull at the bottom of my stomach. An unease that comes with the anticipation of "what next" in a troubled research process, problematic and paradoxical in its very nature as I aim to unsettle colonial, anthropocentric research logics whose histories enable me the position to challenge them now. Slowly at first, she crawls up my torso, sinking her hands into the walls of my innermost flesh as she thrusts herself higher, through my esophagus, sliding across my tongue and expelling boisterously from my mouth. Swollen with affectual sensations of place, thick memories of India fill the air-particles of vibrant red dust that move beyond any solidified account of data, analysis, or qualitative research. I cannot see through the haze. Following Law (2004), if "methods produce realities" then my hope in staying in this hazy place of trouble is that perhaps I might honour India's red dust as always becoming, with a methodology that is grounded in complicated, "unfinished configurations of places, times, matters and meanings" (Haraway, 
2016, p. 1).

Within the field of childhood studies, research is unsurprisingly often focused on children. Situating my pedagogical work within a posthuman research ethic, I am inspired by feminist common worlding methods by Nxumalo (2016), Pacini-Ketchabaw, Kind, and Kocher (2017), Taylor and Pacini-Ketchabaw (2019), and Taylor and Blaise (2014), who propose that it is not only humans who matter in the making of worlds. In this paper, I propose a methodological orientation that decenters the human (researcher and child) and highlights possibilities that emerge when research is conceived as an act of making-with. Disrupting anthropocentric and neoliberal logics of predictable, homogenous, self-making processes, making-with involves a reliance on sympoetic relations of multiple, interdependent components whose trajectories are entangled within "complex, dynamic, responsive, situated, historical systems" (Haraway, 2016, p. 58). Paying attention to materials that exist beyond human selfmaking practices, making-with offers a radical reconfiguration in the construction of knowledge and subjectivities by situating meaning within ineffable, irregular, and impermanent moments with others.

The purpose of this paper is to disrupt what Haraway (1988) refers to as the "god-like trick" of qualitative research, where longstanding ethnographic methodological legacies signify and appropriate complex worlds into a transcendental myth of knowability in the service of an ongoing Euro-colonial rational. Tentatively tracing the movements and emerging storylines of my encounters in India, I attend to the intersections of seemingly disparate materials, specifically a child's pencil and waste materials, and the ways in which they come together/apart and gather meaning among local/global red dust assemblages. In paying attention to how these materials might come to matter in relation with each other (Barad, 2007) and particularly with India's red dust, I highlight the active histories/presences that shape their ontologies with/in this particular place as deeply permeated by colonialism. Moreover, I argue that familiar ethnographic constructs of researcher objectivity separate humans from their relational, felt accountabilities to the places in which they live and, under the guise of political impartiality, reinforce research practices that allow for disconnection and ecological exploitation. Here, I aim to trouble neutralizing research conventions where, as M'charek (2013) so cogently states, "the factness of facts depends on their ability to disconnect themselves from the practices that helped produce them" (p. 436). Using sympoetics as an entry point toward an anticolonial methodological commitment that foregrounds partial, situated knowledges (Haraway, 1988), I highlight the affectual movements of materials within temporal place stories to begin mapping out a research process that is felt, implicated, and messy.

\section{Unsettling ethnographic methods and the ethics of red dust}

Within the context of childhood studies, ethnographic methodologies have often accounted for place as the definable site of research, where naming and ordering phenomena is centralized in the validity of field work. Yet, place has also been reconceptualized as materially discursive (Taylor \& Pacini-Ketchabaw, 2015a), negotiated with felt value (Tuan, 1977), and imbued with sociocultural and political tensions (Tuck \& McKenzie, 2015), tensions that may be unwittingly obscured in the doings of cross-cultural ethnographic research. Criticisms of the colonial nature of ethnographic research are not new. It has been widely argued that systematized ethnographic methods reinforce a positivist desire to attain and disseminate the "truth" of a particular place and are extensions of a colonial desire to manage and control land/bodies (Said, 1978; Smith, 2012). These methods dissolve possibilities for multiple ways of knowing by appropriating difference into existing Western frameworks of study (Argyrou, 2017). Following Nxumalo and Cedillo (2017), these "grand narratives" of Eurocentric action that "center a universal human subject" are particularly common in research within childhood studies (p. 101).

While many qualitative methods encourage researchers to suspend their judgments to eliminate human influence 
and understand the true essence of a lived phenomenon, sympoetics relies on a writer's implication and situated theorizations with/in an event. These theorizations are not simple reproductions of the author's understanding, inherent creativity, or an isolated image of thought (McLure, 2011). Rather, as Ingold and Hallam (2007) write, these artistic resonances are the temporal manifestations of culturally imbued relational movements with others. In this sense, writing, reading, and research are never done alone. Thus, sympoetic thought lives within temporal events that are intimately co-composed with place.

Disrupting the colonial gaze of explanatory qualitative writing, Tuck and McKenzie (2015) have described this sort of living research practice, not by means of method, but of "resonance: a continual process of crafting" (p. 92) that uses theory as a tool to sculpt and (re)sculpt the formation of concepts as they emerge, as opposed to a set of formalized methods. These formations are never whole, stable, or separate from the researcher, and so are permeated with multiple overlapping histories. Yet, noticing and becoming vulnerable to these histories requires a particular onto-epistemological orientation in research. As Haraway (1988) writes, both the researcher and her emerging conceptualizations are eternally partial as both are in part and a part of the world she studies. This partiality is not meant to be controlled or regulated; it is a central quality of sympoetic writing which disrupts ethnographic legacies of a knowable, generalizable subject serving a single story. Sympoetics invites a collision of multiple parts where materials and ideas flow together, fill with intensity, spill, and drop a ripple in the world that provokes us to think. Attuning to the sympoetics of place requires a researcher's embodied implication in all facets of study. As such, researchers must closely attend to sensorial affects of movement with materials and the multiple storylines that come together in ways which unsettle taken-for-granted assumptions about the places in which we live. Sympoetics then, like red dust, becomes a meeting place (Kind, 2010) where past-present-future stories bump up against each other, temporarily settle, and open possible worlds that were previously unimagined.

Despite/with anthropocentric regulatory boundaries, the red dust of India moves in every direction, with multiple others and varying speeds. Red dust moves as an assemblage, an open whole-a relentless ravelling and unravelling of multiple components emerging both within a situated place and among larger subterranean roots that inventively co-configure its movements in relation with others (Colebrook, 2006). The red dust of India is a complex web of contingencies, temporalities that move with the rhythms of its connections. Multiple forms are in constant negotiation within its many paths, and while some may strengthen certain connections at a larger scale, these formations are simultaneously interceded by seemingly small or mundane encounters within situated spaces (Tsing, 2015). Within localized encounters, red dust has the potential to collide with unfamiliar forms in ways that enact novel responses, producing a momentary essence of difference within shifting patterns. Red dust is always in transition and holds no wholly definitive attributes as it mediates among the local/global.

Compacted red dust marks paths of automobiles-a visual distinction of human trajectories from neighbouring jungle terrain. Here, red dust lies heavy on the ground, sedimented by the weight of petrol trucks. Lines are well worn and signal familiar routes-from A to B and back again.

Compacted red dust holds its form.

It tells stories of a long past-present history of transportation that performs with many others across a global stage. Red dust does not exist in isolation. Traced by the imprints of infinite tire tracks, the patterns of its trajectories are a gesture of a complex relation with Singapore, the United Arab Emirates, and the movements of crude oil. Here, compacted red dust is part of a million-year-old storyline that holds no true beginning or end.

Across borders and below the earth's surface, animal and plant bodies are also compacted.

Beyond the scope of human vision, and with the help of sedimented red dust, they compress, heat, and liquify. Extracted-distilled-sold, red-dust-animalplant bodies fuel the livelihoods of many people in 


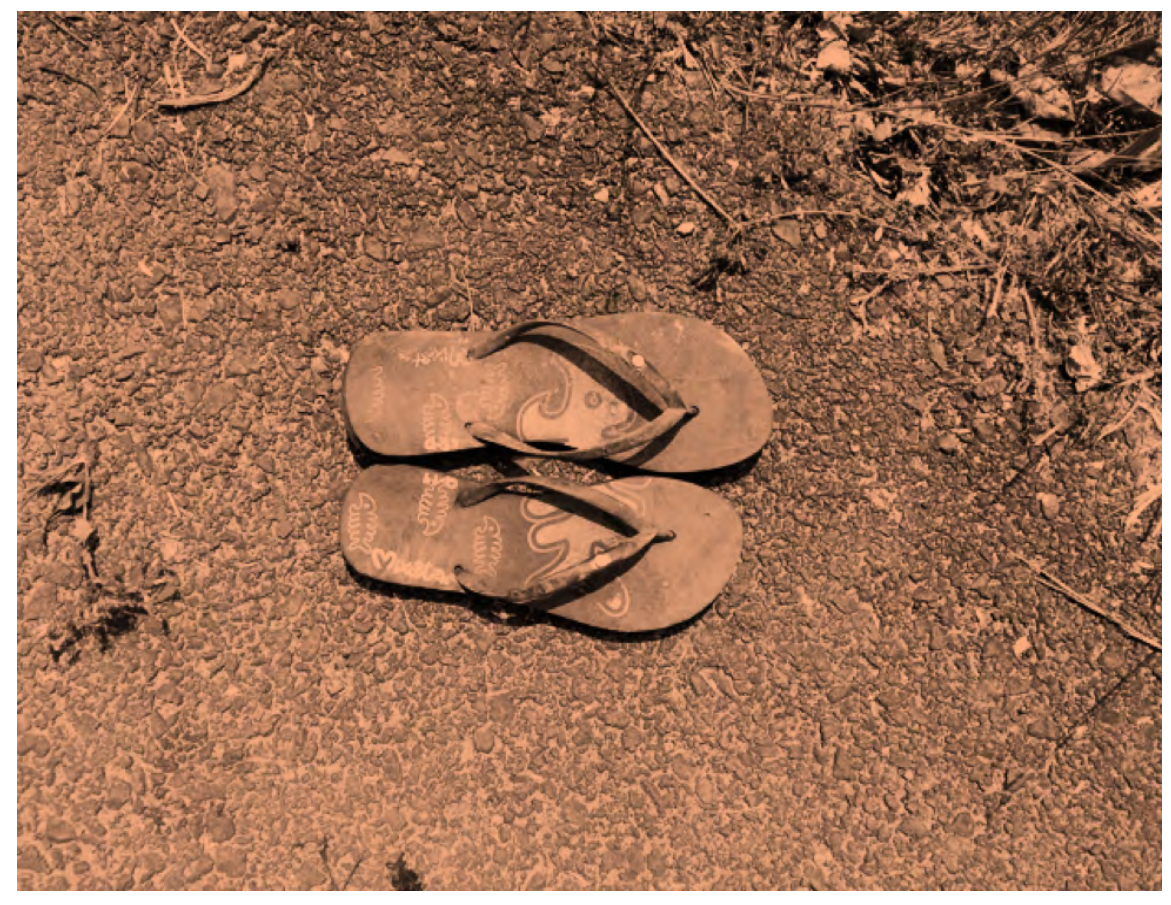

Figure 1. Red dust is a global traveller.
Goa and beyond and are skillfully mediated with/in the rhythms of worldly markets. Red dust relations blur the illusion of a divide between nature and culture and tell contested stories of how humans live entangled lives with red dust assemblages.

When I arrived home from India, the discomfort of signifying red dust with a single story and extracting "findings" among its relations pushed me to abandon my messy desk of data for over two months. Like a cantankerous child, discomfort pushed me away but cried for my attention. My trails were marked with footprints smaller than my own, a tell-tale sign she was following. Always in the back of my mind, she would call me to remember her, regardless of whatever

distraction I tried to find in a bustling Vancouver summer. At the end of each day, I returned to my apartment, where I knew she would be waiting - owning her space in the farthest corner of my living room. She named me a trespasser in my own home. I imagined collecting the fragments of data spread over my desk and organizing them into colour-coded files. Perhaps then I could think logically about this research. Perhaps then she might be quiet. I could find patterns, synthesize my understandings, and present findings in a coherent way. I could return to my composed, scholarly self. In taking up this practice, I learned more acutely about the formations of writer's block.

Through honest conversations with my mentors, Veronica Pacini-Ketchabaw and Sylvia Kind, I was encouraged to go back to the data and this time pay special attention to my encounters with place-to stay with discomfortto locate the histories that inform her and notice her affects. What might discomfort instruct of me if I sat with her tension? What might happen if instead of thinking about, I think with place-close my eyes, open my palms, and feel for flakes of red dust? ${ }^{2}$ Returning to my desk, I try to set aside my more traditional academic intentions and attune myself to the materials that are invoking such intensity. I wonder about what risks might emerge if I relinquish my struggle to see through the haze of red dust. As my fingers trace the contours of relocated matter that blankets my desk, I sense a familiar tugging from the deepest hollow of my body. What are the implications of attempting to pave red dust's transversal movements into readable, linear pathways?

Following Pacini-Ketchabaw, Kind, and Kocher (2017), materials are not empty. Before human encounter, they hold lives and purposes. As I hold on to the eclecticity of the scattered pieces across my desk and become informed by the sensations they create, these materials tell lively stories of the places from which they hail. In this sense, materials are never outside of the place they come from or arrive to-just as every idea I gather in touching them is like a place I have visited (Ingold \& Hallam, 2007). As Ingold and Hallam (2007) write, I may arrive through many different paths, circle around, stay awhile or leave, but each time I revisit an idea, and a material, it is a bit different. Shaped by memories and experiences of my previous visit, it changes, as the world - and I - do not stand still. Each piece of data I hold carries rich histories of the places it has grown from, and its ontology is continually reworked through its relations with others. 
Wrapping my hand around a pencil I received from an educator in Goa, its wood painted yellow and heavy with weight - a child's name etched along its side-I am all of a sudden carrying with it stories of its place. Pastpresent histories of British colonialism in India and the situated particularities of Portuguese rule in Goa reinforce the structures and processes through which this pencil gathers meaning. These histories play out in the daily lives of materials and their ontological significance. This pencil has scribbled through English tests, deciphered mathematical problems, and sketched portraits of the Catholic Saint Francis Xavier. It traces Euro-Western stories of children's psychological development_of ages and stages and fine motor control. Yet, this pencil also scribbles through one-way lines sketched from the global North to South and draws attention to Goa's sustained legacy of local artisanry, traditional drawing practices, and calligraphy. This pencil enacts potential in the brilliantly ordinary moments of children's resistance-of margin doodlings, passed notes, and the hidden artistry of textbook "graffiti." When its work for the day is complete, it rests in a small plastic pencil case decorated with Justin Bieber stickers and tucked inside the cubby of a small wooden school desk. This pencil's marks are of graphite. Extracted from metamorphic rock compound after millions of years of intense sedimentary carbon reduction-solidified dust (collective land/animal/waste particles) — and mechanically recomposed with clay, yellow pencil stories affirm that there are no loose parts within red dust assemblages. The seemingly benign aesthetics of the life of this pencil matter. They are relentlessly mediated among local/global discursivities, colliding with and shaping the formations of the ecologies in which they are situated and, as such, are lively performers in relation with India's red dust.

Materials such as this pencil are not passive or static as if they are merely waiting for humans to act on them; rather, their movements are performed in relentless relation and indeterminacy within human and more-thanhuman worlds (Barad, 2007). Continually regenerating within the socio-political and ecological conditions in which they are positioned, materials do not exist within neutral or solidified spaces. The ways in which this child's pencil lives amid red dust assemblages are highly political as its possible movements are interdependent on its social value within a neoliberal landscape. Following Ahmed (2008), "how we are touched by what comes near" is contingent on the value materials hold within the social configurations in which they are positioned (p. 124). Thus, the histories, presences, and political circumstances of a specific place are manifested in material-encounters. These affects inform how materials come to matter, what they do, and, with this, how humans respond to them. In this way, attuning to the material discursivity of this pencil provokes an attention to the structures and stories which enable it to exist and perform in particular ways. This attention to materials and movements poses ethical obligations that become visible when research is imagined as living, not outside of, but within the flows and poetics of deceptively ordinary everyday life.

Materials are always becoming, forming and reforming amid sticky histories and improvisational gestures of inthe-moment encounters (Ingold, 2013). Despite an anthropocentric imaginary that separates humans from the life of material and natural worlds, humans and materials continually affect and are affected by each other (Barad, 2007). Yet, noticing these affectual entanglements requires that we consider ourselves as vulnerable to and with materials, across shared yet unequal spaces of precarity (Hird, 2012). This onto-epistemological commitment to collective ecological life with others has been central in Indigenous knowledges for millennia (Hunt, 2014; Tuck, 2010) and continues to unsettle colonial dichotomies of nature/culture that reinforce human superiority and land exploitation. Following Tuck and McKenzie (2015), if researchers are to pay attention and respond to ongoing colonial histories at play in encounters with materials, then place must first be rethought beyond methodological 
frames that subjugate its passivity:

Place is not merely a neutral backdrop, a bounded and antiquated concept, or only a physical landscape ... place is mobile, shifting over time and space and through interactions with flows of people, other species [and] social practices. At a more localized level, place both influences social practices as well as performs and (re)shapes through practices and movements of individuals and collectives. Place is interactive and dynamic due to time-space characteristics. Disparate realities determine not only how place is experienced but also how it is understood and practiced (e.g., in relation to culture, geography, gender, race, sexuality, age, or other identifications and experiences). (Tuck \& McKenzie, 2015, p. 635)

Humans are in perpetual relation with place, and thus place is integral to colonial practices. Methods which distance humans from their connections with place disregard past-present histories, possible futurities, and the socio-political tensions with which place is entwined. This positioning of place as merely a vacant stage for human activity perpetuates a dichotomy of active humans / inactive nature that is embedded within colonial rationalities of human control and conquest over natural worlds (Taylor, 2017). |In this sense, meaning is extracted from ecological origins and appropriated into easily digestible fragments. The multiple others who once nourished it are wrung out and deemed excessual.

These logics of fragmentation allow for continual settler exploitation and appropriation of Indigenous lands and erasures of Indigenous bodies (Nxumalo, 2016; Simpson, 2014). Under the mask of methodological neutrality, the banality of this violence becomes possible when knowledge is conceived within Euro-Western research measures that pacify the liveliness of more-than-human worlds and the political discourses at play in humanplace relations. Thus, movement toward more ethical, politically conscious research accountabilities in the field of childhood studies necessitates that methodologies "grapple with, interruptively respond to, as well as work through the doubts, complicated frictions, discomforts, knots and silences" (Nxumalo, 2016, p. 641) that already live in everyday encounters with place-if we choose to notice them.

Connections with place are deeply imbued with/in colonial systems. Therefore, it is impossible to remember my experiences with place, and the red dust of India, without also remembering the colonial histories/presences whose intersections position me now to think and write against them. Sympoetics may offer a possible yet risky entry point to writing with place in ways that are situated within paradoxical and contingent storylines and insistent on the irreducible difference of local knowledges. In rethinking place as discursively alive with particular histories and presences with which I am entangled, my research process becomes explicitly informed by its intensities, sensations, and the multiple stories its materials provoke. In this way, my positionality here as a settler-researcher is implicated, imperfect, and attentive to poetics which aim to disrupt the knowability of childhoods and place. This approach requires a place-specific, relational ethic that moves beyond commonly accepted institutionalized thought in academia (Berry, Do Nascimento, \& Pacini-Ketchabaw, 2018) whereby the researcher maintains a clean distance from the messiness of lived experience. Following Haraway (1988), this situated partiality decenters the positivist illusion of a researcher's objectivity and names her as vulnerable to and with place. At this location, the myth of the innocent, all-seeing researcher is no longer available, and as Haraway (1988) writes, is where "the knowing self is partial in all its guises, never finished, whole, simply there and original; it is always constructed and stitched together imperfectly, and therefore able to join with another, to see together without claiming to be another" (p. 586). In this way, grounding the construction of knowledges in partial material encounters calls on researchers to become accountable to research that is contaminating to, and contaminated by, place. This work is nontranscendental and nonneutral, specific to felt values of a particular place and subsequently lives with/in what are often tensioned, uncomfortable spaces of difference. 
Approaching my data with linear thought processes that seek to extract, codify, and analyze place relations not only enacts violent assumptions of knowability but also effectively enhances a distance from lived accountabilities to materials and place. Enacting this separation makes it possible to disregard the existence of Indigenous peoples whose epistemologies, ontologies, and cosmologies are so intricately braided here. Under the veil of objectivity, qualitative research processes are better able ignore red dust assemblages as mediated among racialized, gendered, socio-political power axes-relentlessly spilling past even the most sealed boundaries of Cartesian categorical thought. In relinquishing discomfort and finding ease in an assurance of clean, controlled bias and measurable findings, the consequences of my work are no longer mine. Rather, they live within institutionalized mechanics of modern research procedure. Despite my supposed sterility and superiority, their effects linger. In this way, an ethical obligation to research with place demands much more than methodological logics that are steeped in anthropocentric separation, as the affectual livelihoods of materials move far beyond any human-conceived form. With this said, my messy desk of data is oozing with reverberations from India and their aftershocks throb with a provocation: How might I grapple with/in/out-of place in a response that is both inventively ephemeral and consequential?

The ephemeral red dust of India finds its way into every crevice. The bottoms of my feet, deep in my nail beds, coating my nostrils, ear canals, eyelidsbetween my teeth. Riding my bike, it sweeps into my eyes, and as tears fall down my cheeks, the red dust of India rolls with salty droplets. Clinging to my chin, and letting go. Falling back to the earth, where it is swept up again into bodies of the next. Red dust is a global traveller and carries strained stories of its journeys with human others-of who we are and what we do. Crossing borders and settling in spaces that defy illusive barriers regulating globalization. The red dust of India ingeniously moves in pathways beyond human control-a lively swarm of porous particles which carry billions of microbes across land, air, and water. Microbial bacteria, fungi, pollution, skin cells, and flora, red-dust-organisms are the moving in between of life and death among vibrant global ecologies.

Instructed by discomfort, I notice past-present histories alive in my encounters with red dust. Sympoetics allows me the space to better hear discomfort, hover in in-between spaces, and pay attention to the training I have received as a settler-colonial subject to inertly exempt myself from my entanglement with these more-than-human ecologies. As I struggle to reimagine where this sort of research process might take me and what ripples it may produce, I cannot help but wonder, how have past-present colonial dreams of production and social efficiency separated me from my entanglement and accountabilities with place-and to what consequence?

Growing up in a dominantly Western culture, rooted in the coproduction of capitalism and science (Smith, 2012), I have been nurtured with an ideological sense of social separation from the land I walk on. Neoliberal descriptions of the place I live in might infer that I am indeed existing in a sort of bubble-the human world, a place that is disconnected, even superior, to the organic spaces around it. In my Vancouver home, I live with walls around me, I walk on a floor suspended from the earth, and I look outside through the protection of glass windows. My skin is warm, my feet are clean, and I hold an assurance of safety in a man-made isolation. Beneath my kitchen sink, swept dust and household garbage are kept in a plastic bin. I seal its lid, hiding the pungent smell of rotting waste, thrown out materials and my accountability to their violence. I wonder, where is "out"? Living within neocolonial structures that reinforce the illusion of a divide between nature and culture, I become quickly detached from the grounding histories of place and the socio-political conditions that allow me the privilege of benefiting from the myth that I am indeed separate, even superior. With concrete and glass framing my experiences, dust buried at the bottom of my garbage bin and waste materials out of sight in darkened cupboards, how have I been engaging with place, and to what capacity? 
As Hird (2012) highlights, "nature relentlessly flows, but not in ways that are necessarily compatible with human flourishing" (p. 464). While some humans have the ability to ignore these flows in ways that maintain consumptive logics and preferred neoliberal lifestyles, waste materials continue to thrive in lively, interdeterminate relations that effectively leak past the boundaries of waste containers and human imaginaries. Hird's $(2012,2013)$ studies of the microbial underground of landfills illuminate that most of the transformative action of waste materials happens well beyond human engineering capacities. Following systems' bacterial undergrowth, Hird demonstrates how waste materials engage in complex processes of making with others - of sympoiesis. Collectively metabolizing discarded objects and producing leachate, microbial bacteria cogenerate compositions of liquid, often toxic, constituents that seep into surrounding water, soil, plant, and animal bodies. Despite human attempts to control leakages, these vigorous waste ecologies continue to coproduce inventive social forms that exist in the inhuman domain of "geobacteria liveliness" (Hird, 2012, p. 458).

These inventive social formations initiated by capitalist modernity are not new phenomena, nor are they geographically contained. More than halfway across the globe, children in Goa often hold visibly intimate relationships with waste materials. The discourses of global consumerism manifest here as an intricately designed and expansive system of slums made entirely of reimagined wastetreasures. Here, the vibrant life of waste holds a visible ontological livelihood in relation with human

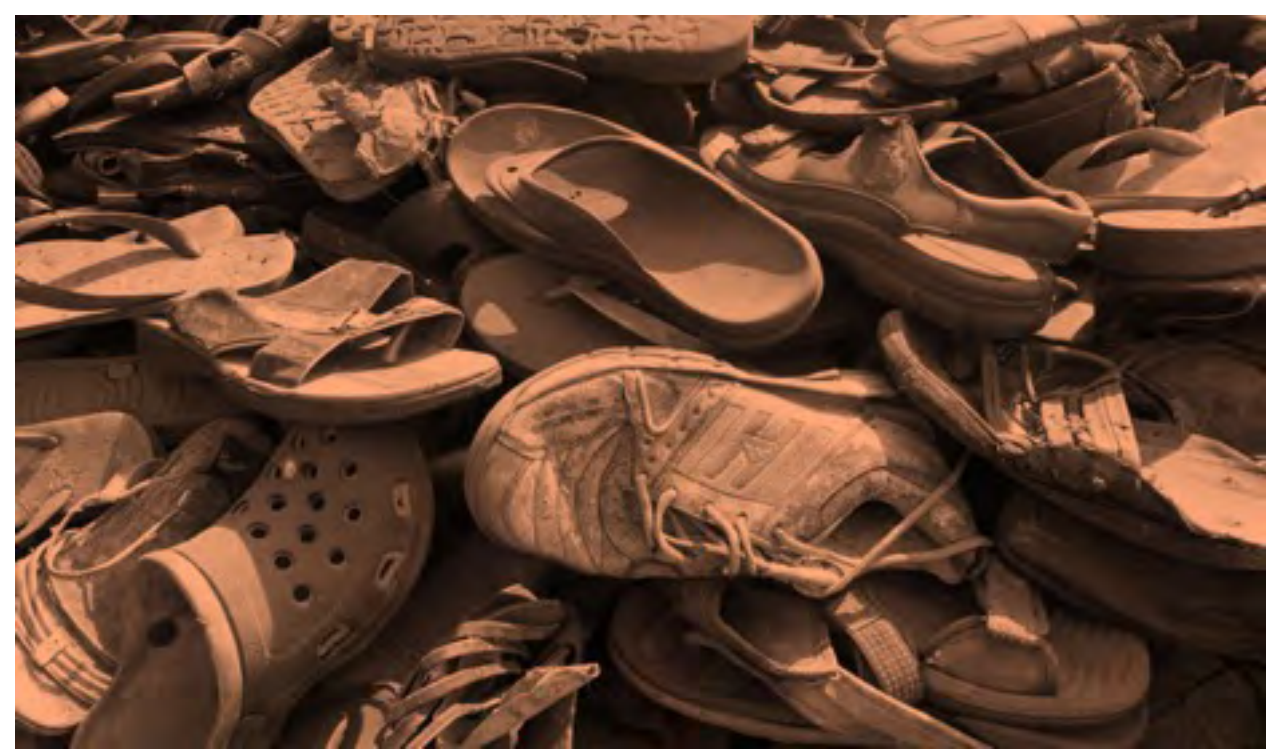

Figure 2. Attention to materials and movements poses ethical obligations. and more-than-human others, demonstrating the "inherent indeterminacy of the world rendered determinate, by human and inhuman alike” (Hird, 2013, p. 465). Community-built and ever-evolving, the slums are bustling with people and materials from every corner of the subcontinent. Human and waste materials live here in contingent and contradictory relationships that continue to push the gravitational limits of horizontal and vertical space-a never-ending game of waste-based Jenga. Mountains of plastic bottles and colourful bits of trash that line the streets here are more than merely human excess, they take shape in this place as playgrounds for school children and troughs for wild pigs and dogs-among infinite other uses. A close friend who is local to this place would often tell me, "anything is possible in India."

While the global distribution of wealth allows Western countries such as Canada to afford solid waste management systems that place garbage "out of sight and out of mind" (Hird, 2013), families in Goa often have little access to regular trash collection. Their lives become intimately entangled with the physicality of waste materials and the toxicity they bring. Many of the families I spent time with in India live in homes with aluminum-sheet walls and holes where the sun and wind peek through, the kitchen floor is compacted dust, and the windows are recycled meshed wire. A home is shared with an ecology of uninvited local critters and changing weather-the lines distinguishing human and natural worlds are inevitably blurred. Here, both red dust and waste move beyond boundaries of inside/outside and are a visual indication of common worlds where there is no "out" there. In 
noticing the movements of red dust, its global blockages and flows among humans, waste, and other worldlings, it becomes apparent that encounters with red dust are strongly mediated by race, gender, and socioeconomic geographies.

"Nothing is free in India."
"But ... it's garbage."
"Even if it's trash on the side of the road,
it usually belongs to somebody.
Broken pipes, old coconut leaves, rope and wire.
Someone will use these things.
You think it's dirty, but somebody wants it. Especially if you do."

As an emerging scholar situated in Western mechanisms of educational progress, I exist in a neoliberal social landscape that tends to look ahead rather than around. I consider what it means to be "forward thinking" as I research with place in the context of childhood studies. I wonder what might happen if I shift my gaze, notice place, its materials - and pay intimate attention to the contingent, uneven natures of the where of research (Tuck \& McKenzie, 2015). Attuning to the lively doings of the place in which I am a visitor and the violent histories heavy in its materials, I am learning that being critically informed by the place I am engaging with requires me to pay attention to "spatialized processes of settler colonialism ... and extend beyond considerations of the social to more deeply consider the land, materials, non-human inhabitants and their characteristics as they determine and manifest place" (Tuck \& McKenzie, 2015, p. 635). Moving away from research methods that seek to regulate my experiences as separate and superior to the dynamic happenings of place, sympoetics attunes to affective, contradictory, and partial readings of data as events that move beyond human reason. With this conceptualization of place, seemingly disparate materials — red dust, a pencil, and waste materials - come to matter because of their relationalities within common worlds and the ongoing colonial histories/presences that inform their ontologies. In this way, researchers are called to pay attention to their implication with/in movements of past/present, local/ global assemblages and the lively performances of more-than-human others. Thinking with sympoetics of place, I am better able to situate my knowledge as eternally fragmented and teased up in white-bodied, settler-colonial past/present trajectories and attend to the politically contested and transformative possibilities of materials and place in research.

\section{Thinking with red dust formations}

India's red dust is so much more than tiny particles of land and waste matter. It has an unparalleled ability to move in-between solidified forms. Situated in the space between one and other, between is often a taut, non-neutral physical location of difference. A research ethic that embodies an ethos of red dust requires a responsiveness to the unfamiliar that is sparked in these in-between spaces, where research must stay with the trouble of an unanswerable question (Haraway, 2016). These encounters between one and other cultivate an affectual pulse that reverberates in suspended conjunction, where one and other meet with sustained distinction. In this way, the unknowability of the other is the basis of artistic engagement (Cinquemani, 2018) and of the sympoetics of place. Through the use of sympoetics, I do not seek to relay "what happened" in India, explain phenomena or moral judgments; rather, I aim to allude to "a condition" in which I find myself while doing, making, and creating within a particular place and time (Phelan \& Rogoff, 2001, p. 34). Attuning to this condition provokes a careful attention to others and the past-present histories that inform their movements. Like red dust, sympoetics is never stable or knowable. Rather, it tentatively gathers form through a composition of words, rhythms, their collective imperfections, and the subjectivities of those who read it across locations of difference. 


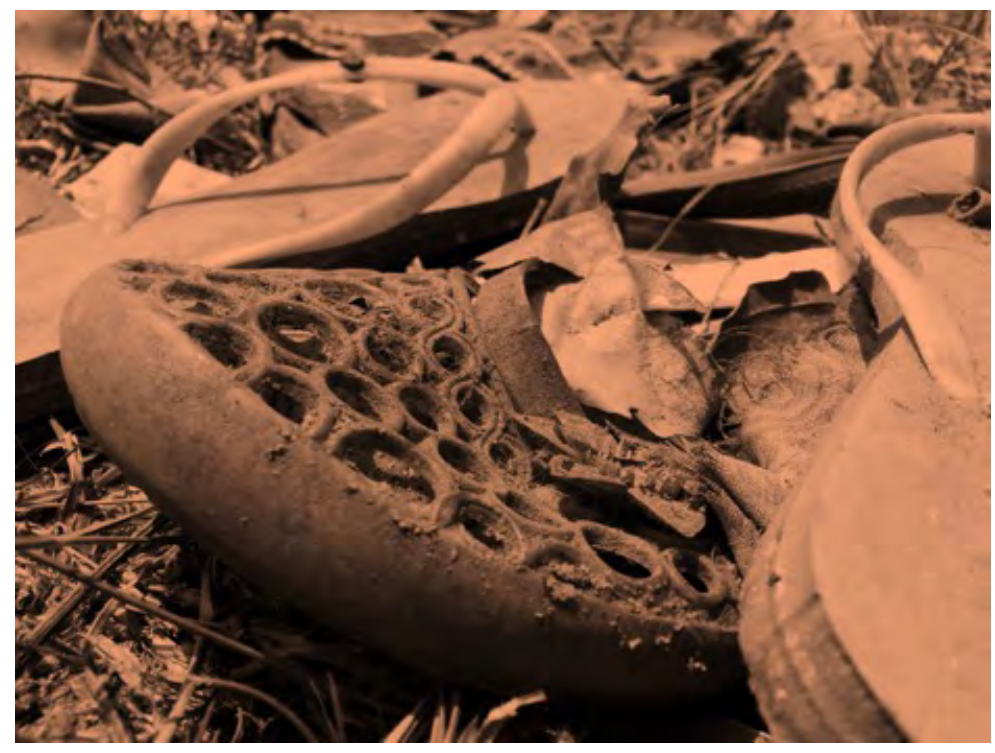

Figure 3. Like red dust, sympoetics is never stable or knowable.

Haraway (1988) writes that as researchers we ought to make room for "surprises and ironies at the heart of all knowledge production" (p. 594). She asserts "we are not in charge of the world. We just live here and try to strike up noninnocent conversations by means of our prosthetic devices" (p. 594). As I think with the sympoetics of red dust, I foreground that this writing is not complete; it is not to be taken as a whole story or direct translation of experience. Saturated in my own partiality as I encounter the ever-dynamic happenings of materials and place, my presence is entangled, not only with the place where I live, but also with the places where I have lived-the multiple histories and sensational geographies of my existence up to this point, as well as the potential for beyond. I situate sympoetics as temporal, messy, and in many ways intentionally incoherent, to make space for affectual resonances that fall beyond solely textual accounts. I aim to twist the spirit in new and unfamiliar directions (Springgay, 2008), wrenching the body's affectual response and disallowing the comfort of a familiar thought. I play with words and rhythm to shape my experiences with India in a tentative body. In no way are sympoetics able to capture India as a place-that is not the point. More so, sympoetics allows me to craft meaning as tentative, becoming, and eternally co-compositional. It gives me a platform to notice, to grapple with, and to complicate what it means to be a visiting researcher on lands likely colonized by my own European ancestors, as I continue to benefit from the position I have gained through these histories. This is my untidy attempt at making sense of pedagogical work in ways that highlight the banalities of settler colonialism at play in ethnographic research and the troubles of common sense. Through artful attentiveness and processes of sympoetic interpretation, my intention is to attune to the very possibility of relations across un/common worlds and my accountabilities toward thinking research as otherwise.

Swaying the wheels of my chair back and forth, hearing them roll across my wood floor, I sit at my desk with discomfort and notice a change in our project. Merely inviting her, sitting with her, is not enough, it risks my eventual acceptance and her ultimate disappearance. Thinking sympoetically with place requires me to actively contribute to her irregularities, and provoke a perpetual unease that dances alongside her temporal formations. To notice and attend to place in ways that move like red dust. Slow, twisted, and tentative, I start to etch out a map of my data. This is merely a place for beginnings.

India is a kaleidoscope that never stops turning She is a bag of marbles that makes her own probability A tipped over paint truck whose colours seep into every crevice A force of smells

Of bread, of sewage, of metal, and sweets Of life, death, and everything in between She tastes of humidity - thick, wet Flavours of cumin, of chili, of cinnamon and sweat Dry red dust that speckles every body upon her land She is a 500 pound load upon a rusty 2 wheeler 
The seemingly impossible, inventive and able

A fast-forwarded race through a maze with no end A concert orchestra in the disjointed swells of their warm up Every instrument in the throes of a score - existing in time, never on it A short straw among others, a tossed coin that never lands

She begins from the middle and tells of no end

She is the grey, the sticky, the messy between A magical fall down a rabbit hole and an honest slap of reality She is not a picture to be taken, or destination on a map She is a series of combustions, of conflict and confusion Strung with beads of temporal clarity She is an event Colourful and vibrant in her happenings She rests only for a second, in places beyond the familiar She is a sister's smack and a mother's hug A child's giggle and a father's belt A grandmother's stare and a neighbour's honest wave She is the wildness of impulse held together by duty

A climb to the top, the familial pursuit of survival She is the anomaly of a moment from chaos-hovering in pause She gives a million reasons to pull it all apart, and one love to keep it together

She is a winding ride on a coastal highway A salty taste of air, of skin She is the sweat on my brow and the dust in my nails

The scrapes on my legs and the hope in my heart She is the curiosity of a million lost pieces And the glue that holds them in hand Loud, ravenous, and present in her quarrels

She is a quiet mind in the busiest of places She is the city, the desert, the mountains and the plains A Bengali morning and an Arabian nightShe is calm, but never asleep She is the clanging of tin cups and the smoothness of masala chai She is a tight grip on the doors of a rail cart, and the freedom of the body that sways outside She is the heartbeat that echoes through car horns, market calls, and charging animals The comings and goings of 3 oceans that meet at her base A mix-matched quilt of 29 states and 150 languages She's made of cows, of pigs, 30 pound rats And a billion human lives She is the law of the people, the morally criminal

The malice of some, and the passion of many

The ill, the grieving, the ones who give up

The lost, the cheated, the unspoken code Of love, of hate and of the ways in which things get done 
The inexplicable coherence of millions of lines Dancing in every direction with the speed of a hummingbird's wings She is the sweat between bodies, The fluid in pathways that lubricates movement Never seen and always felt She is the generosity, the forgiveness, the love that holds space The heart of the universe and the mind of its creatures he is the inherent potential that lies in every single molecule of this place And the movement that will keep them going

Her colours never contained Her probability never made and her kaleidoscope eye never still 


\section{References}

Ahmed, S. (2010). The promise of happiness. Durham, NC: Duke University Press.

Argyrou, V. (2017). Ontology, "hauntology," and the "turn" that keeps anthropology turning. History of the Human Sciences, 30(1), 50-65. https://doi.org/10.1177/0952695116684310

Barad, K. (2007). Meeting the universe halfway: Quantum physics and the entanglement of matter and meaning. Durham, NC: Duke University Press.

Berry, A. (2017). Becoming affected with artistic memoir: Entanglements with arts-based education in India (Master's thesis). Retrieved from http://voyager.library.uvic.ca/vwebv/holdingslnfo?bibld=3861698

Berry, A., Do Nascimento, A., \& Pacini-Ketchabaw, V. (2018). Pedagogies of care: Thinking-with and paying attention. International Child and Youth Care Network, 235, 49-57. Retrieved from http://www.cyc-net.org/cyc-online/sep2018.pdf

Cinquemani, S. (2018). Artistic encounters: Ethical collaborations between children and adults. In C. Thompson \& C. Schulte (Eds.), Communities of practice: Art, play, and aesthetics in early childhood (pp. 61-76). New York, NY: Springer.

Colebrook, C. (2006). Deleuze: A guide for the perplexed. London, UK: Continuum.

Haraway, D. (1988). Situated knowledges: The science question in feminism and the privilege of partial perspective. Feminist Studies, 14(3), 575-599. doi:10.2307/3178066

Haraway, D. (2016). Staying with the trouble: Making kin in the Chthulucene. Durham, NC: Duke University Press.

Hird, M.J. (2012). Knowing waste: Towards an inhuman epistemology, Social Epistemology, 26(3-4), 453-469. https://doi.org/10.1080/0 2691728.2012.727195

Hird, M.J. (2013). Waste, landfills, and an environmental ethic of vulnerability. Ethics and the Environment, 18(1), 105-124. doi:10.2979/ ethicsenviro.18.1.105

Hunt, S. (2014). Ontologies of indigeneity: The politics of embodying a concept. Cultural Geographies, 21(1), 27-32. https://doi. org/10.1177/1474474013500226

Ingold, T. (2013). Making: Anthropology, archaeology, art, and architecture. New York, NY: Routledge.

Ingold, T., \& Hallam, E. (2007). Creativity and cultural improvisation: an introduction. In E. Hallam \& T. Ingold (Eds), Creativity and cultural improvisation (pp. 1-24). New York, NY: Berg.

Kind, S. (2010). Art encounters: Movements in the visual arts and early childhood education. In V. Pacini-Ketchabaw (Ed.), Flows, rhythms, and intensities of early childhood education curriculum (pp. 95-109). New York, NY: Peter Lang.

Law, J. (2004). After method: Mess in social science research (1st ed.). London, UK: Routledge.

M'charek, A. (2013). Beyond fact or fiction: On the materiality of race in practice. Cultural Anthropology, 28(3), 420-442. https://doi. org/10.1111/cuan.12012

McLure, M. (2011). Child as totem: Redressing the myth of creativity in early childhood. Studies in Art Education, 52(2), 127-141. doi:1 $0.1080 / 00393541.2011 .11518829$

Nxumalo, F. (2016). Towards "refiguring presences" as an anti-colonial orientation to research in early childhood studies. International Journal of Qualitative Studies in Education, 29(5), 640-654. https://doi.org/10.1080/09518398.2016.1139212

Nxumalo, F., \& Cedillo, S. (2017). Decolonizing place in early childhood studies: Thinking with indigenous onto-epistemologies and black feminist geographies. Global Studies of Childhood, 7(2), 99-112. doi:10.1177/2043610617703831

Pacini-Ketchabaw, V., Kind, S., \& Kocher, L.L.M. (2016). Encounters with materials in early childhood education. New York, NY: Routledge.

Phelan, P., \& Rogoff, I. (2001). “Without”: A conversation. Art Journal, 60(3), 34-41. doi:10.2307/778135 
Said, E. W. (1978). Orientalism. New York, NY: Pantheon Books.

Simpson, L.B. (2014). Land as pedagogy: Nishnaabeg intelligence and rebellious transformation. Decolonization: Indigeneity, Education, \& Society, 3(3), 1-25. Retrieved from https://jps.library.utoronto.ca/index.php/des/article/view/22170/17985

Smith, L.T. (2012). Decolonizing methodologies: Research and Indigenous peoples (2 ${ }^{\text {nd }}$ ed.). London, UK: Zed Books.

Springgay, S. (2008). Body knowledge and curriculum: Pedagogies of touch in youth and visual culture. New York, NY: Peter Lang.

Taylor, A. (2017). Beyond stewardship: Common world pedagogies for the Anthropocene. Environmental Education Research, 23(10), 1448-1461. doi:10.1080/13504622.2017.1325452

Taylor, A., \& Blaise, M. (2014). Queer worlding childhood. Discourse: Studies in the Cultural Politics of Education, 35(3), 377-392. https:// doi.org/10.1080/01596306.2014.888842

Taylor, A., \& Pacini-Ketchabaw, V. (2015a). Learning with children, ants, and worms in the Anthropocene: Towards a common world pedagogy of multispecies vulnerability. Pedagogy, Culture, \& Society, 23(4), 507-529. doi:10.1080/14681366.2015.1039050

Taylor, A., \& Pacini-Ketchabaw, V. (2015b). Introduction: Unsettling the colonial places and spaces of early childhood education in settler colonial societies. In V. Pacini-Ketchabaw \& A. Taylor (Eds.), Unsettling the colonial places and spaces of early childhood education in settler colonial societies (pp. 1-19). New York, NY: Routledge.

Taylor, A., \& Pacini-Ketchabaw, V. (2017). Kids, raccoons, and roos: Awkward encounters and mixed affects. Children's Geographies, 15(2), 131-145. doi:10.1080/14733285.2016.119984

Taylor, A., \& Pacini-Ketchabaw, V. (2019). The common worlds of children and animals: Relational ethics for entangled lives. New York, NY: Routledge.

Tsing, A.L. (2015). The mushroom at the end of the world: On the possibility of life in capitalist ruins. Princeton, NJ: Princeton University Press.

Tuan, Y. (1977). Space and place: The perspective of experience. Minneapolis: University of Minnesota Press.

Tuck, E. (2010). Breaking up with Deleuze: Desire and valuing the irreconcilable. International Journal of Qualitative Studies in Education, 23(5), 635-650. doi:10.1080/09518398.2010.500633

Tuck, E., \& McKenzie, M. (2015). Relational validity and the "where" of inquiry: Place and land in qualitative research. Qualitative Inquiry, 21(7), 633-638. doi:10.1177/1077800414563809

(Endnotes)

$1 \quad$ This paper is based on my master's thesis research (Berry, 2017), which explored children's entanglements with waste materials through a series of art events at a school in Goa, India.

2 Reframing my research approach toward thinking with, versus about, place is inspired by Affrica Taylor and Veronica Pacini-Ketchabaw's writings on thinking-with $(2015 b, 2017)$ and a working paper by my doctoral colleague Kelly MacAlpine. 